there are very few of the people in part III whom Dr Roberts feels could be in sheltered housing; they are already there or being looked after reasonably successfully in their own homes.

Despite this increasing burden there is no guidance from on high which will enable useful change to occur. Social service departments feel constrained to operate within existing guidelines and until these are changed do not feel able to improve staffing ratios or employ skilled nursing help.

The old people's homes should become nursing homes but not State institutionsdumping grounds for handicapped old people waiting to die. Most parts of the country have no community hospitals and little likelihood of getting them for several years. There is no reason why the old people's homes should not be used by both primary care and social services as community hospitals, with day care, short-term admissions, and both medical and social rehabilitation forming a large part of the activity within the institution.

The need for hotel care for the privileged few has disappeared. We must all devise new ways of coping with an increasing problem, not spend effort on yearning for the "good old days."

Oxford Area Health Authority

J S RODGERS

(Teaching),
Headington,
Oxford

Oxford

1 Department of Health and Social Security, Priorities for Health and Personal Social Services in England.
London, HMSO, 1976.

"The cholecystogram is normal" ... but...

SIR,-Mr M H Gough's excellent article on gall bladder disease (9 April, p 960) is a timely reminder of the important part that clinical judgment still plays in accurate diagnosis. The accompanying figure is from a young woman with recurrent upper abdominal pain and shows a normal cholecystogram while the excised gall bladder is the seat of typical cholesterosis and multiple tiny calculi. The patient had had a normal cholecystogram on two occasions but her own doctor, Dr G B Malone Lee, who had seen her on several occasions during the acute attacks, was convinced that these were typical of biliary colic although there was no jaundice and he insisted that cholecystectomy was indicated. $\mathrm{Mr}$ Gough has performed a useful service in drawing attention to this important and prob-

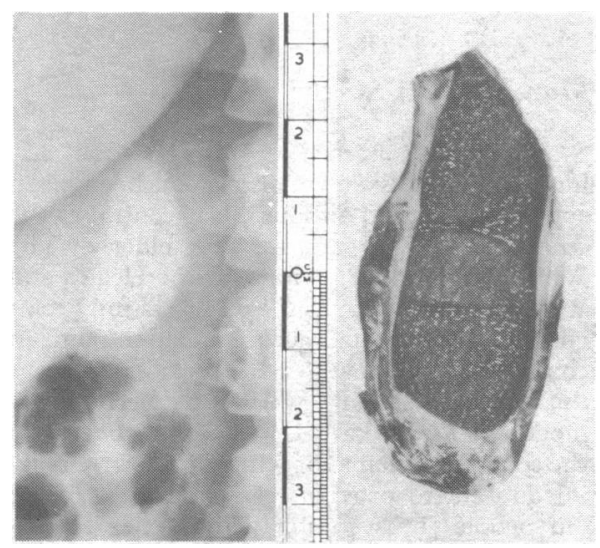

Normal cholecystogram (left) and postoperative appearance of same gall bladder (right). ably not very uncommon source of misdiagnosis.

GeORGE Qvist

London W1

indicated what salary levels should be, irrespective of pay policy. This is not so; the TSRB's recommendations for the nationalised industry boards were put forward on exactly the same basis as those for the other three groups within its terms of reference in October 1974 (Report No 6) for implementation from 1 January 1975; but, as you say, they have not yet been implemented. The Government's pay restraint measures were, of course, announced on 11 July 1975 and were effective from that date. The position as it affects the recommendations for MPs and Ministers is very much the same: the TSRB's Report No 7 was put forward on 13 June 1975 and recommended a salary for MPs for implementation on that date; Report No 8 was put forward in June 1976 and recommended levels of remuneration for Ministers that were appropriate also at 13 June 1975 (that is, before the introduction of the restraint measures) as the second part of a three-part "Parliamentary" review which had begun early in 1975 and related to salaries that had last been brought up to date in 1972. They were in no sense notional salaries, although again, as you rightly say, some got nothing and some got a much reduced rise.

A further point of clarification arises about the 1975 increases that took salaries over $£ 13000$ : in practice they were staged (not "frozen"), but the second stage has not of course yet been paid. You may also like to know that Sir Peter Menzies ceased to be a member of the Review Body on Top Salaries at the end of 1971 on becoming chairman of the Electricity Council. There has in practice been no cross-membership between it and the Doctors' and Dentists' Review Body since then. studies on a total of 43 women premenstrual tension" " the authors failed to demonstrate any statistically significant differences between bromocriptine and placebo.

Thus at present there is no clear evidence that bromocriptine is effective in either mastalgia or premenstrual tension. It is precisely this lack of controlled trials that has caused such confusion in the past over the efficacy of diuretics in this condition, and it is important that bromocriptine should not follow suit. We are currently carrying out a controlled trial of bromocriptine against placebo in order to define the drug's role in the treatment of mastalgia patients.

R E MANSEL

P E PREECE

L E Hughes

University Department of Surgery,

Welsh National School of Medicine,

1 Preece, P E, et al, Lancet, 1976, 2, 670

Martin-Cronin, J, et al, Obstetrics and Gynecology, 1976, 48, 703.
Schulz, K-D, et al, Archiv für Gynäkologie, 1975, 220, 83. Lancet, 1976, Harrison, P, and Letchworth, A T, in Proceedings of Symposium on Pharmacological and Clinical Aspect of Bromocriptine (Parlodel), May 1976, p 103. London, Sandoz Ltd, 1976

Ghose, K, and Copper, A, British Medical fournal, $1977,1,147$.

\section{Review Body}

SIR,-Perhaps I might take up one or two questions of fact arising from the interesting and informative Briefing on the Review Body (7 May, p 1228).

In discussing Review Body approaches to Government pay policies, you say that on two occasions the Review Body on Top Salaries
London WC2

JEAN ORR

***We regret that our information about Sir Peter Menzies was incorrect and we apologise to him and to our readers for any misunderstanding that this may have caused.-ED,

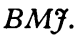

SIR,-Not for the first time it would appear that the Review Body is going to report too late for its recommendations to be finalised for the quarterly payments due to medical practitioners on 30 June. This means that yet again money earned and expenses incurred from 1 April 1977 will in fact not be paid in full until 30 September 1977 at the earliest.

A similar delay for "administrative reasons" in the payment of Schedule D income tax now attracts interest to the rate of $9 \%$. What is sauce for the goose. . . .

Hugh T FAY

Stockport, Cheshire

\section{Future staffing in community medicine}

SIR,-I read with interest Dr Keith Young's article (30 April, p 1173) and must accept many of his points. However, he appears to include as medical professional activities for community physicians only epidemiology, medical statistics, information service, and the control of environmental health. One of the most vital problems in the Health Service has been for many years the planning and orientation of services, and, while this may be called an administrative function, the involvement of practitioners in community medicine can be
Office of Manpower Economictor, 